\title{
Analysis of workability, mechanical strength and durability by the FT-IR method of concrete based on silica-limestone sand preserved in aggressive environments
}

\author{
Tarek Djedid \\ Laboratory of exploitation and valorisation of Sabaran energy resources "LEVRES "Department of Hydraulic and Civil \\ Engineering, Faculty of Technology, University of El-Oued, 39000, Algeria \\ tarek-djedid@univ-eloued.dz. \\ Mohammed Mani \\ Department of Hydraulic and Civil Engineering, Faculty of Technology, University of El-Oued, 39000, Algeria \\ m.mani39@gmail.com
}

\author{
Abdelhamid Guettala \\ Research Laboratory in Civil Engineering "LRGC» \\ University Mohamed Khider Biskra, BP 145 RP, 07000 Biskra, Algeria \\ guettalas@yahoo.fr
}

\author{
Abdelkader Hima* \\ Department of Electrical Engineering, Faculty of Technology, University of El-Oued, 39000, Algeria \\ Abdelkader-bima@univ-eloued.d₹, bttp://orcid.org/0000-0002-5533-3991
}

\begin{abstract}
The interest of using combined sand of equal percentage of silica and limestone becomes evident in the formulation of compacted concrete in several previous works around the world due to the formidable percentage of fines that improves the compactness and increases various mechanical resistances, which produces a more durable construction against different probable aggressions.

This paper examines the effect of using this type of sand on workability, compressive strength, flexural strength, and splitting tensile strength. A durability test was consulted using infrared spectroscopy to assess diverse types of hydration products formed. The obtained results show clearly the advantages of using sand with silica and limestone grains $(50 / 50) \%$ in ordinary concrete infected by aggressive water. There is also an improvement in compactness, different mechanical resistances, and a reduction in the formation of harmful hydration products.
\end{abstract}

\section{OPEN ACCESS}

Citation: Djedid, T., Mani, M., Guettala, A., Hima, A., Analysis of workability, mechanical strength and durability by the FT-IR method of concrete based on silica-limestone sand preserved in aggressive environments, Frattura ed Integrità Strutturale, 59 (2022) 566-579.

Received: 28.09 .2021

Accepted: 19.12.2021

Published: 01.01.2022

Copyright: (C) 2022 This is an open access article under the terms of the CC-BY 4.0, which permits unrestricted use, distribution, and reproduction in any medium, provided the original author and source are credited. 
KEYwORDS. Silica-limestone sand; Concrete; Workability; Mechanical strength; Infrared spectroscopy.

\section{INTRODUCTION}

$\mathrm{S}$ and is the second most used material in the world after water. Fifteen billion tons of sand are extracted every year, mainly for construction (roads and concrete manufacturing). It takes 200 tons of sand to build a single house and 30.000 tons of sand for one kilometer of road [1]. In order to meet the growing needs, industrials are exploiting huge quarries, dredging rivers and seabed with sometimes disastrous ecological consequences. The increasing extraction of natural sand in riverbeds is causing many problems, losing water, deepening river courses and provoking bank slides, loss of vegetation on river banks, etc. [2,3]. One of the adopted methods to reduce the environmental impact of the construction industry is the use of alternative raw materials [3-5] by partially or totally replacing the constituents of concrete in order to reduce the total cost of construction.

Aggregate properties affect the durability and performance of concrete, so fine aggregate is an essential component of concrete and cement mortar. The most commonly used fine aggregate is natural river sand. Fine and coarse aggregate account for about $75 \%$ of the total volume of concrete [6]. It is therefore important to obtain an abundant alternative aggregate of good quality on site as the aggregate forms the main matrix of the concrete or mortar. One of the problems encountered in achieving adequate workability in concrete and mortar mixtures based on crushed limestone sand is the increased water demand. This adverse effect is mainly due to the presence of a high percentage of fines, the shape and texture of the crushed sand. This increase in water demand can be reduced by using super plasticizers [7-9]. Cement and Concrete of Australia (CCAA) [10] indicates that the shape and texture of aggregate particles have a significant influence on the workability of freshly mixed concrete, as they affect the water demand and the water-cement ratio.

T. Shanmugapriya and R. N. Uma [11] reported that the optimum percentage of replacement of natural sand with crushed limestone sand is $50 \%$. The results also revealed that increasing the percentage of partial replacement of cement with silica fume increased the compressive and flexural strength of high performance concrete. Puneeth, G. T. and Mamatha, A [12] reported that the optimum percentage of manufactured sand and microsilica were $50 \%$ and $15 \%$ respectively. The concrete with this percentage of micro silica and manufactured sand has higher compressive, tensile and flexural strength than conventional concrete. Nisnevich et al [13] showed that lightweight concrete containing thermal power plant rejects and quarry sand had a strength multiplied by 2 or more when the crushed sand was close to $50 \%$.

Prakash, Rao, and Giridhar, Kumar [14] deduced that concrete cubes containing crusher sand developed about 17\% higher compressive strength, more than $7 \%$ higher tensile strength, and $20 \%$ higher flexural strength than concrete cubes and prisms with river sand as fine aggregate. Vasumathi [15] examined the strength of concrete by partially replacing cement with fly ash and natural sand with quarry sand. It is concluded that there is a gain in strength at young age, but the strength does not increase at least after 28 days and workability decreases.

There are other researchers who reported that the semi-substitution of river sand by crushed limestone sand participates in the reduction of the porosity of concrete and contributes to the improvement of its strength and durability. The southeastern region of Algeria suffers from the penury of the river sands and the rising of groundwater phenomenon. In addition, waters in this region are loaded with chlorides $(\mathrm{Cl})$ and sulphates $\left(\mathrm{SO}_{4}^{-2}\right)$ and strongly affected the stability and durability of constructions. Therefore, this work investigates the effects of the semi-substitution of river sand by crushed limestone sand (at the same W/C ratio and plasticity range) on several properties of fresh and hardened concrete. The performance and durability of the concrete formulation were evaluated through the measure of various parameters i.e. slump, density of fresh concrete, compressive strength, flexural strength, tensile strength, and infrared spectroscopy.

\section{MATERIALS}

\section{Cement}

7 he used cement in this experiment is of type CEMI42.5N-LH/SR5 (sulfate resistant cement). It comes from the cement factory of Ain El Kebira, Setif (Algeria), whose physico-chemical and mineralogical characteristics are indicated in Tab. 1. 


\section{Aggregates}

Two types of sand were used during this work; the first is a river sand (RS) that comes from the sand pit of Asila sandpit (El Meghaier, Algeria), and the second is a crushed sand (CS) that is brought from the quarry refusals of Ben Brahim (Hassi Messoud, Algeria).

RS has a continuous particle size distribution ranging from 0.08 to $5 \mathrm{~mm}$ with a fraction of grains smaller than $0.08 \mathrm{~mm}$ is about $1 \%$. However, the particle size of CS is altered between 0.08 and $3 \mathrm{~mm}$ with a proportion of grains smaller than 0.08 mm being about $17 \%$ (Fig. 1).

Two types of gravels are used G1 (3/8) and G2 (8/16) of the same mineralogical source as CS. The main physicalmechanical and chemical characteristics of the used aggregates are presented in Tab. 2. The mineralogical analysis by XRD shows us the siliceous nature of RS, and the essentially calcareous nature of CS (Fig. 2).

\section{Adjuvant}

The used admixture in this formulation is a brown super plasticizer with a high water reducer which makes it possible to obtain very high quality concretes and mortars. It is supplied by the company GRANITEX and marketed under the name: MEDAPLAST SP 40, with a density of $1.20 \pm 0.01$, a PH of 8.2, and a chloride content $<1 \mathrm{~g} / 1$, in accordance with the standards NF EN 934-2 and NA 774. The authorized percentage by the manufacturer is $0.6-2.5 \%$ by weight of cement depending on the performance required.

\section{Technical requirements of formulation}

The cement dosage is $400 \mathrm{~kg} / \mathrm{m}^{3}$ and the same strength class of concrete C $30 / 37 \mathrm{MPa}$ has been chosen for all the studied formulations.

The used method in the preparation of concrete is the graphical method of Dreux Gorisse [16]. Two compositions of concrete were made in this context; the first is based on $50 \%$ substitution of river sand by crushed limestone sand [9] named $\mathrm{C} 1$, and the other is a control concrete $\mathrm{C} 0$ of $0 \%$ limestone sand to access the comparison.

In order to choose a suitable percentage of $\mathrm{W} / \mathrm{C}$ and super plasticizer, three $\mathrm{W} / \mathrm{C}$ ratios were tested $(0.4,0.42,0.43)$ and for each ratio, two percentages of super plasticizer were used ( 2 and $2.5 \%$ as upper limits allowed by the manufacturer).

For the follow-up of this investigation, five time periods were proposed $(28,60,90,180,360$ days $)$ in order to guarantee the effect of this formulation stored in a moderately aggressive environment (based on an equal percentage of fine siliceous and calcareous grains) on the different mechanical strengths and the results given by infrared spectroscopy.

\begin{tabular}{|c|c|c|c|c|c|c|c|c|c|c|}
\hline \multicolumn{11}{|c|}{ Chemical composition ( $\% \mathrm{wt}$ ) } \\
\hline $\mathrm{CaO}$ & $\mathrm{Al}_{2} \mathrm{O}_{3}$ & $\mathrm{SiO}_{2}$ & $\mathrm{Fe}_{2} \mathrm{O}_{3}$ & $\mathrm{Na}_{2} \mathrm{O}$ & $\mathrm{SO}_{3}$ & $\mathrm{~K}_{2} \mathrm{O}$ & $\mathrm{Cl}^{-}$ & IR & Loss on ignition & Free $\mathrm{CaO}$ \\
\hline 63.69 & 4.55 & 20.9 & 5.03 & 0.18 & 2.08 & 0.33 & 0.001 & 0.75 & 0.7 & 0.75 \\
\hline
\end{tabular}

$\begin{array}{llll}\text { Mineralogical composition (\%) } & & \\ \mathrm{C}_{3} \mathrm{~S} & \mathrm{C}_{2} \mathrm{~S} & \mathrm{C}_{3} \mathrm{~A} & \mathrm{C}_{4} \mathrm{AF} \\ 67.35 & 3.33 & 16.2\end{array}$

Physical and mechanical properties

Specific gravity $\left(\mathrm{g} / \mathrm{cm}^{3}\right)$

Blaine specific surface area $\left(\mathrm{cm}^{2} / \mathrm{g}\right)$

Initial set (min)

Final set (min)

Consistency of cement paste (\%)

Strength class (MPa)

Table 1: Characteristics and composition of the used of cement. 


\begin{tabular}{|c|c|c|c|c|}
\hline \multirow{3}{*}{ Type } & \multicolumn{2}{|l|}{ Sand } & \multicolumn{2}{|c|}{ Gravel } \\
\hline & \multirow[b]{2}{*}{ RS } & \multirow{2}{*}{ CS } & CG & \\
\hline & & & $3 / 8$ & $8 / 16$ \\
\hline $\begin{array}{l}\text { Apparent volumetric mass } \\
\left(\mathrm{g} / \mathrm{cm}^{3}\right)\end{array}$ & 1.65 & 1.44 & 1.43 & 1.40 \\
\hline Absolute volumetric mass $\left(\mathrm{g} / \mathrm{m}^{3}\right)$ & 2.55 & 2.55 & 2.72 & 2.45 \\
\hline Fineness modulus & 2.29 & 2.62 & - & - \\
\hline Compactness (\%) & 62 & 56 & 52 & 57 \\
\hline Porosity $(\%)$ & 38 & 44 & 48 & 43 \\
\hline Void ratio & 61 & 78 & 92 & 75 \\
\hline Visual Sand equivalent (\%) & 71.37 & 80.87 & - & - \\
\hline Piston Sand equivalent (\%) & 72.65 & 82.60 & - & - \\
\hline Aggregate cleanness (\%) & - & - & 98.84 & 99.95 \\
\hline Water absorption after $24 \mathrm{~h}(\%)$ & 2.13 & 4.1 & 2.38 & 3 \\
\hline Flatness coefficient $(\%)$ & - & - & 17 & 14 \\
\hline Los Angeles testing (\%) & - & - & 24 & 25 \\
\hline Water content $(\%)$ & 1.73 & 0.6 & 0.45 & 0.45 \\
\hline Methylene blue test & 1.5 & 0.8 & - & - \\
\hline
\end{tabular}

Table 2: Physical, mechanical and chemical properties of aggregates.

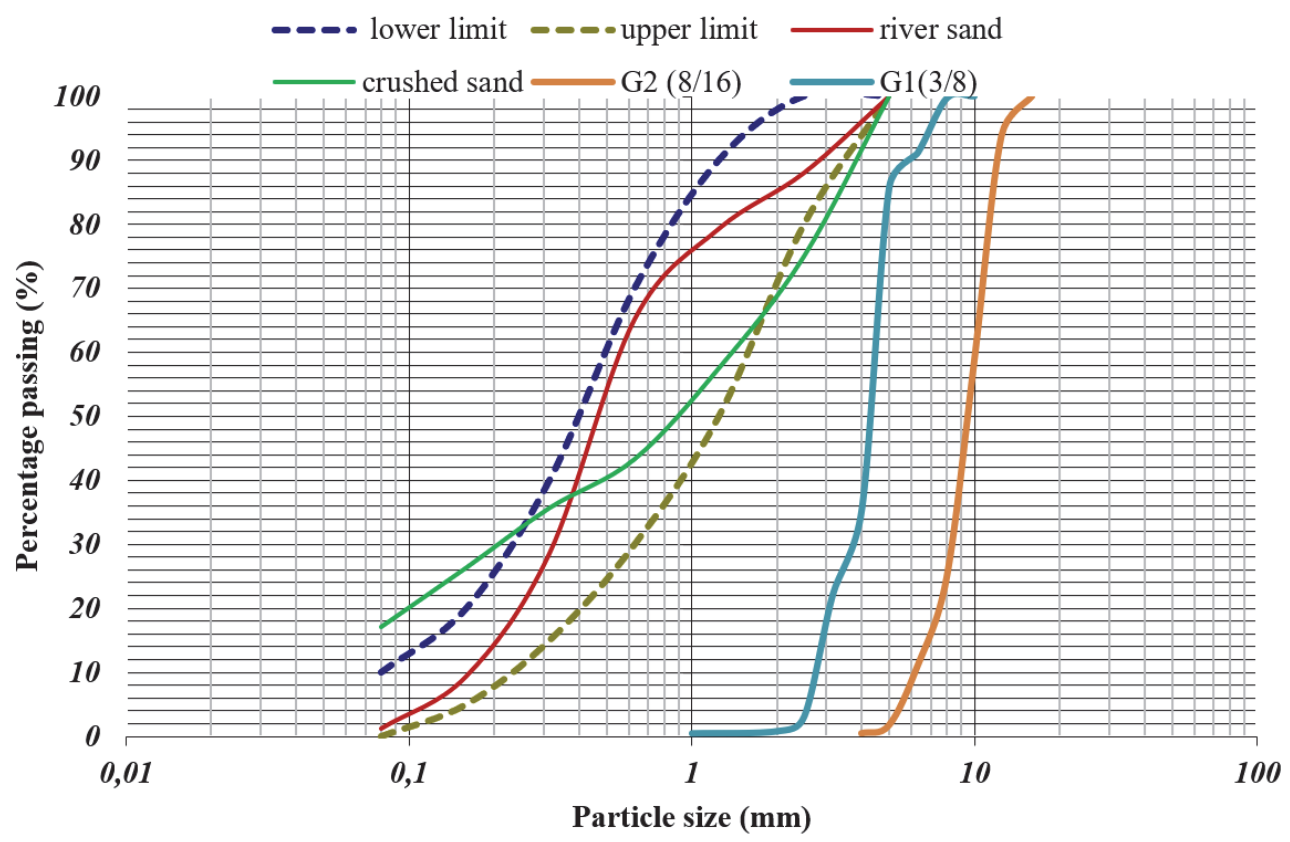

Figure 1: Size analysis of the studied aggregates.

\section{EXPERIMENTAL PROCEDURES}

wo tests were carried out in the fresh state, the first is the Abrams cone slump test according to the specification of EN 12350-2 [17]. The other is the density determination test according to the recommendations of EN 12350$6[18]$. The aim was to optimize the water and super plasticizer dosage to reduce the overall pore volume [19].

Three types of moulds were used, $100 \times 100 \times 100 \mathrm{~mm}$ cubes for compressive strength, $70 \times 70 \times 280 \mathrm{~mm}$ prisms for flexural strength, and $110 \times 220 \mathrm{~mm}$ cylinders for tensile strength (Brazilian test). The execution of these mechanical strengths is performed according to the European standards, i.e. EN 12390-3, EN 12390-5 and EN 12390-6 respectively [20-22]. 
Count

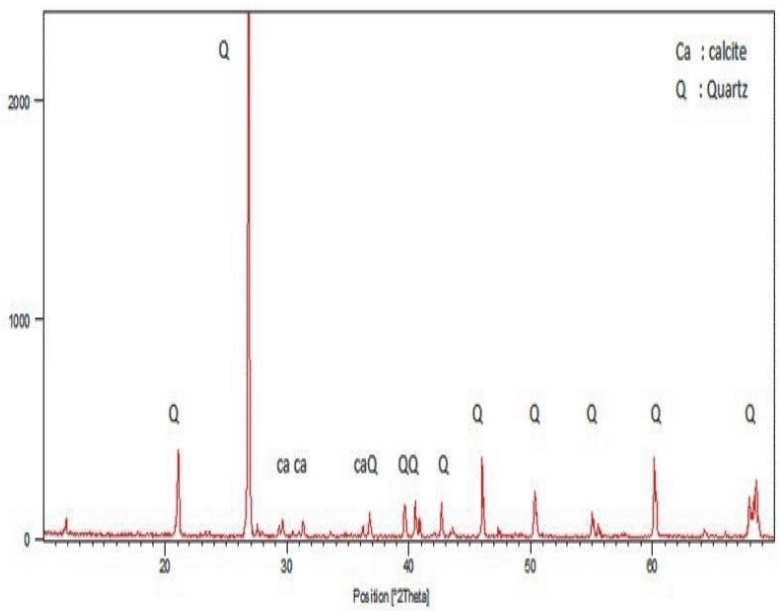

(a)

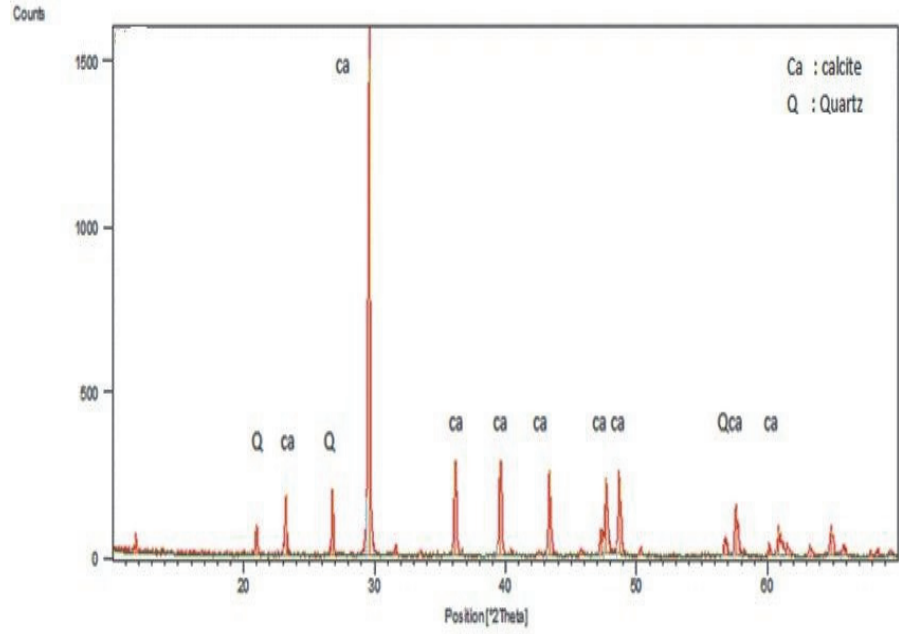

(b)

Figure 2: XRD analysis of investigated sands: (a) RS, (b) CS.

FT-IR spectroscopy is a technique that is based on the interaction between IR radiation and a sample which can be solid, liquid or gas. It measures the frequencies at which the sample absorbs the radiation as well as the intensity of these absorptions. The frequencies are useful for identifying the chemical composition of the sample because the chemical functional groups are responsible for absorbing radiation at different frequencies. The concentration of a component can be determined from the absorption intensity.

This test is performed at the laboratory of chemical research of the University of El Oued at the age of 360 days.

FT-IR spectra were recorded using a SHIMADZU IRAffinity-1 spectrophotometer. The spectra of the concrete samples were recorded by grinding the samples into powder, mixing the powder with a small amount of $\mathrm{KBr}$ (potassium bromide) powder $(0.198 \mathrm{~g} \mathrm{KBr}$ powder $+0.002 \mathrm{~g}$ concrete) and compacting the mixture into a disk. Specifically, the mid-infrared frequency range (4000 to $400 \mathrm{~cm}^{-1}$ ) with a resolution of $8 \mathrm{~cm}^{-1}$. Thirty scans were recorded each time.

\section{Environmental conditions}

To accelerate the degradation process, the concrete specimens are exposed to three chemically aggressive environments of water rising in three locations (named A, B, C) of El Oued region (Algeria) during one year. It should be noted that wetting-drying cycles are opted for after the first twenty-eight days of continuous immersion in drinking water, which represents a total of 22 wetting-drying cycles of up to 360 days. The concentrations of the chemical elements through these environments are represented in Tab. 3. It is also worth mentioning that these environments can be considered as moderately aggressive environments XA2 [23].

The specimens are naturally dried in the open air, which was more relevant for the service conditions. A wet-dry cycle lasted 15 days. First, the specimens were continuously immersed in each environment for 7 days, and then were put in the open air to dry naturally for another 8 days $[24,25]$.

\section{Designation of specimens and aggressive environments}

$\mathrm{COA}, \mathrm{COB}$, and $\mathrm{COC}$ : Ordinary concrete specimens based on river sand (siliceous) in each environment A, B and C subjected to wetting-drying cycles.

C1A , C1B, and C1C: Ordinary concrete specimens based on 50\% quarry sand (limestone) and 50\% silica sand in each environment $\mathrm{A}, \mathrm{B}$ and $\mathrm{C}$ subjected to wet-dry cycles.

C1A IC, C1B IC, and C1C IC: Ordinary concrete specimen based on 50\% quarry sand (limestone) and 50\% silica sand in each environment $\mathrm{A}, \mathrm{B}$, and $\mathrm{C}$ subjected to continuous immersion.

Environment A: rising waters from the Chott area.

Environment B: rising waters from the Sidi Mastour area.

Environment C: rising waters from the Sahane 1 area. 


\begin{tabular}{|c|c|c|c|c|c|c|c|c|c|c|c|c|}
\hline & PH & $\mathrm{T}$ & Sal & $\mathrm{Ca}^{+2}$ & $\mathrm{Mg}^{+2}$ & $\mathrm{NH}_{4}{ }^{+}$ & $\mathrm{Cl}^{-}$ & RS & $\mathrm{HCO}_{3}-$ & $\mathrm{NO}_{3}^{-}$ & $\mathrm{NO}_{2}^{-}$ & $\mathrm{SO}_{4}^{-2}$ \\
\hline & & ${ }^{\circ} \mathrm{C}$ & $\%$ & \multicolumn{9}{|c|}{$\mathrm{mg} / 1$} \\
\hline Env A & 7.71 & $10-22$ & 4.1 & 761.5 & 140.9 & 0.53 & 5739.8 & 4400 & 185.44 & 7.05 & 0.47 & 2610.81 \\
\hline Env B & 7.35 & $10-22$ & 7.7 & 689.3 & 165.2 & 0.6 & 2290.2 & 10400 & 488 & 3.79 & 0.04 & 1119 \\
\hline Env $C$ & 7.44 & $10-22$ & 9.6 & 521.0 & 680.5 & 0.23 & 4956.3 & 7200 & 229.36 & 2.59 & 0.04 & 2120 \\
\hline
\end{tabular}

Table 3: Physico-chemical characteristics of rising waters.

\section{RESULTS AND ANALYSIS}

\section{Effect of substitution on workability}

7 rom the results of Fig. 3, it is noticed that the slump rate increases with increasing water and super plasticizer 1 dosages for both types of concrete. Comparing the results of $\mathrm{C} 0$ and $\mathrm{C} 1$, it is undoubtedly stipulated that the shape of the grains and the nature of the texture are the most responsible for the workability of the concrete [26].

Fig. 4 shows the high densification of $\mathrm{C} 1$ with $\mathrm{W} / \mathrm{C}$ equals to 0.42 and the percentage of super plasticizer in relation to the weight of cement of $2.5 \%$. On the other hand, the concretes $\mathrm{C} 0$ with $\mathrm{W} / \mathrm{C}$ equal to 0.42 and SP percentages equal to $2 \%, 2.5 \%$ are almost comparable. This situation states that the ratio of $\mathrm{W} / \mathrm{C}$ is 0.42 and the percentage of super plasticizer of $2.5 \%$ becomes the most suitable for this formulation.

The workability of concrete is made with $50 \%$ substitution of river silica sand by crushed limestone sand which is much more influenced by the amount of water and super plasticizer they introduce due to the high specific surface area of the limestone fines. However, in order to keep a good densification and an excellent quality of the plastic concrete in accordance with the position of a more compact and durable concrete, it was necessary to choose the right volume of water and to increase the quantity of admixture until a workable mixture was obtained.

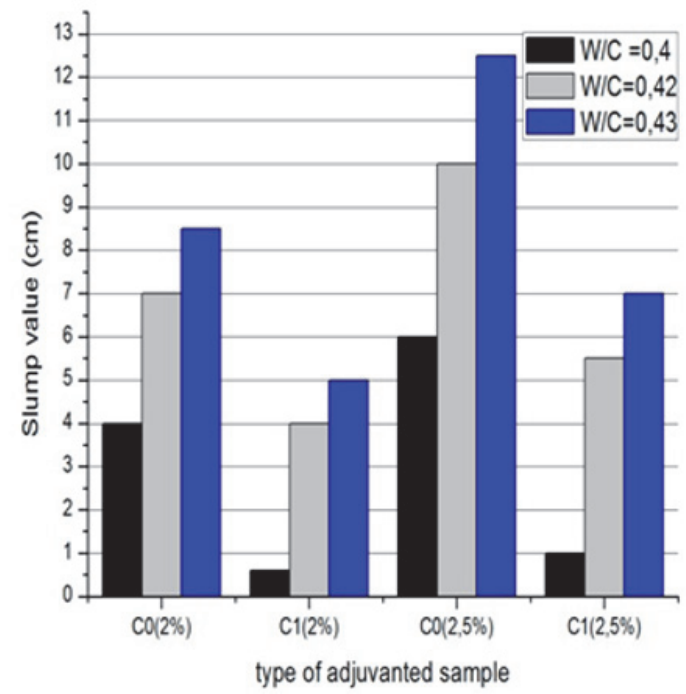

Figure 3: Slump rate of $\mathrm{C} 0$ and $\mathrm{C} 1$ as a function of $\mathrm{W} / \mathrm{C}$ and percentage of SP.

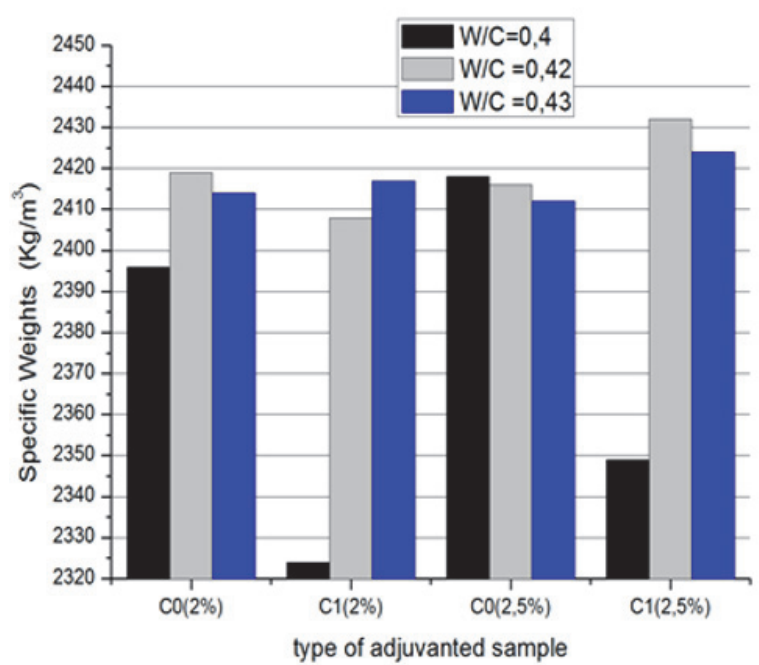

Figure 4: Density of $\mathrm{C} 0$ and $\mathrm{C} 1$ as a function of $\mathrm{E} / \mathrm{C}$ and percentage of SP.

An excellent correlation equation (Fig. 5) between the slump values and the specific weights is obtained in the fresh state of all the formulations tested with different $\mathrm{W} / \mathrm{C}$ and super plasticizer dosage has the value $\boldsymbol{Y}=\mathbf{0 . 1 8} \boldsymbol{X}^{\mathbf{3}}-\mathbf{4 . 9 3} \boldsymbol{X}^{2}+\mathbf{4 2 . 5 6} \boldsymbol{X}$ +2304.6 , and the correlation coefficient $\boldsymbol{R}^{2}=\mathbf{0 . 9 5}$, where Y represents the specific density values and $\mathrm{X}$ represents the slump values. This predictive equation has been adapted in the case of ordinary concrete based on alluvial sand or silicalimestone sand (50/50) \% where W/C is between $0.4-0.43$ and SP content is between $2 \%$ and $2.5 \%$. 


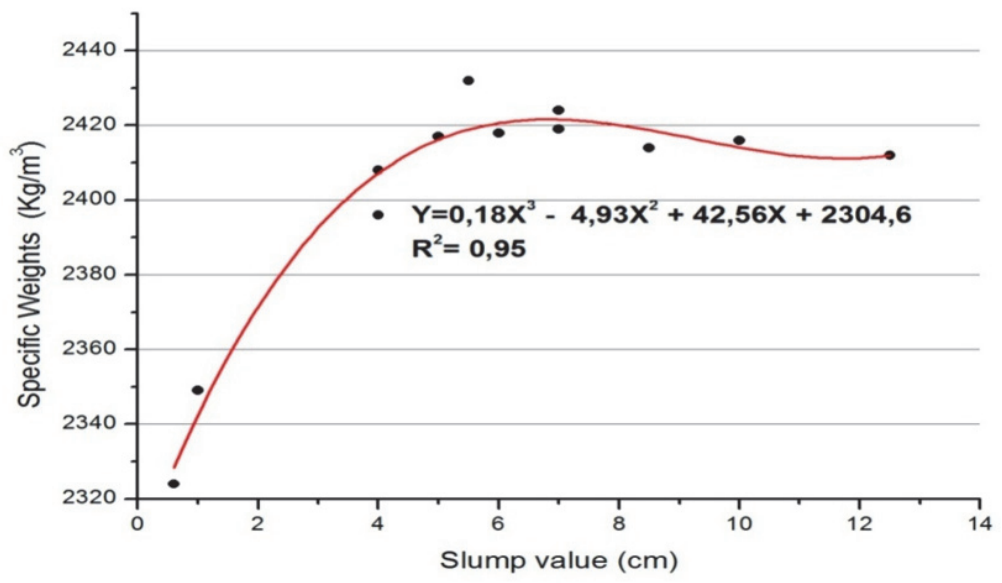

Figure 5: Relationship between the slump values and the specific weights obtained in the fresh state.

\section{Effect of substitution on mechanical strength: Compressive strength}

Compressive strength is an important characteristic of concrete and one of the main parameters of this research. The compressive strength has been measured at different times. It represents the average of the strengths of a series of three cubic specimens subjected to crushing.

Compressive strengths were monitored on $10 \times 10 \times 10 \mathrm{~cm}$ specimens subjected to alternating cycles of wetting-drying and continuous immersion in groundwater until the day of testing. Fig. 6 shows the compressive strength values at different measurement times: 28, 60, 90, 180, and 360 days.

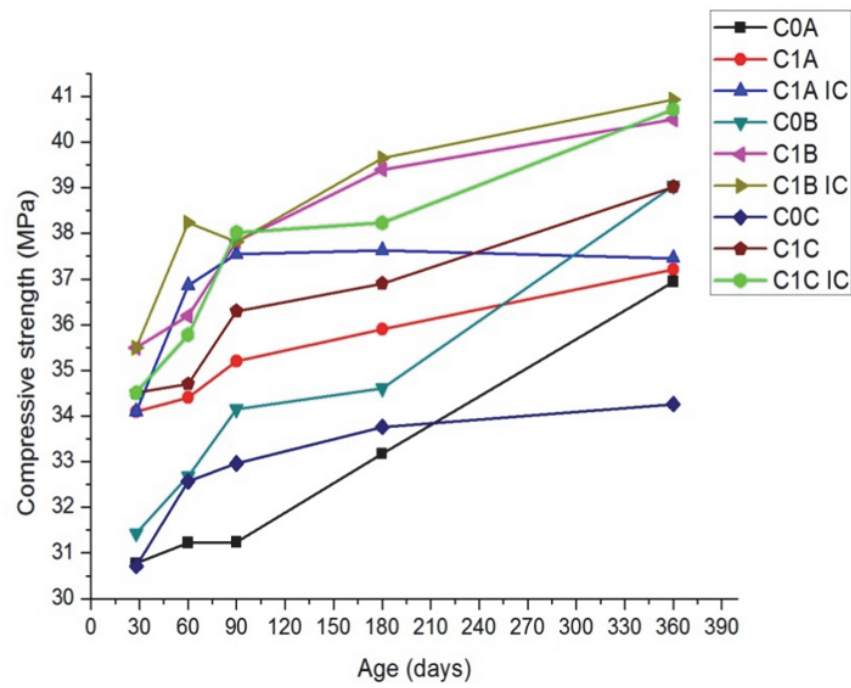

Figure 6: Evolution of compressive strengths of different concretes in environment A, Band C.

The results show that the compressive strengths of $\mathrm{C} 0, \mathrm{C} 1$ and $\mathrm{C} 1 \mathrm{IC}$ concrete in all environments often increase with age and do not show any decrease except for a slight reduction of the compressive strength of C1 IC in environment $\mathrm{A}$ at the age of 360 days by $0.45 \%$ compared to that at the age of 180 days.

When comparing the strength values at 360 days, C1 concretes have better compressive strengths than C0 (control) concretes in all environments. In fact, $\mathrm{C} 1$ concretes with a 50\% limestone sand base and whatever the storage condition (C1 IC contained immersion, C1 wetting -drying) present a superiority in the development of mechanical compressive performance compared to the C0 control (wetting -drying) of the order of $1.40 \%, 0.73 \%$ in environment $\mathrm{A}, 4.84 \%$, $3.74 \%$ in environment $\mathrm{B}$ and $18.82 \%, 13.89 \%$ in environment $\mathrm{C}$ respectively.

The increase in compressive strength of C0A between 28 and 360 days (Fig. 6) is due to the crystallization of new products in the voids of the interfacial transition zone by slow chemical reactions between the cement paste constituents and the aggregate, formation of calcium silicate hydrates in the case of siliceous aggregates. These interactions then contribute to the development of the strength over time [19]. 
Furthermore, the mechanical behavior of $\mathrm{C} 1$ concrete is constantly immersed in the aggressive waters of environments $\mathrm{A}$, $\mathrm{B}$ and $\mathrm{C}$ and it is therefore better than the same concrete kept alternately. These results are in agreement with those found by the United States Bureau of Reclamation which states that the rate of degradation of an alternately immersed specimen for one year is equivalent to that degraded under continuous immersion for eight years [27-29].

In this case and up to the age of one year, the existence of $50 \%$ of limestone sand in the cement matrix is infected by aggressive species resulting from the phenomenon of rising water considerably, improves the compressive strength. This is due to the appropriate percentage of fines which promote capillary pore sealing and thus gradually increase the compressive strength. This was confirmed by Priyanka [30] who proved that the substitution of $50 \%$ of natural sand by artificial limestone sand in the mortar mix, presents an excellent compressive strength especially with a W/C ratio equal to 0.5. Another assertion was provided by Adams [31] who said that the substitution of natural sand by $50 \%$ of crushed limestone sand in high performance concrete presents a better compressive strength of concrete.

\section{Effect of substitution on mechanical strength: Flexural strength}

Fig. 7 shows the flexural strength values at the different ages mentioned above. The results indicate that most of the flexural strength values of the different types of concrete in all environments peak at the age of 180 days and then were decreased at the last maturity at 360 days with the exception of $\mathrm{C0A}$ and $\mathrm{C} 1 \mathrm{~A}$ IC of environment A, which peaked at the age of 60 days and $\mathrm{C} 1 \mathrm{C}$ IC of environment $\mathrm{C}$ that shows its highest value at 90 days.

These values can provide an overall indication of the intensity of aggressiveness of each environment. Thus it can be said that environment $\mathrm{A}$ and $\mathrm{C}$ and especially $\mathrm{A}$ are more severe than environment $\mathrm{B}$, as also shown in Tab. 3. Generally the values of the mechanical strength to compression and bending are more optimized in environment $\mathrm{B}$, then in $\mathrm{C}$ respectively, while environment $A$ is characterized by lower values than the other two mentioned above.

In our investigation, we observed optimum values of flexural strength of $\mathrm{C} 1$ type concrete in all environments at the age of 180 days, of the order of $11,10.38$ and $7.98 \mathrm{MPa}$ respectively in A,B, and C. These figures no longer persist and will be reduced by $38.36 \%, 23.12 \%$, and $1.12 \%$ successively at age 360 days. This scenario explains that the hydration products, especially C-S-H and $\mathrm{CH}$ evolved gradually, until that time, the harmful hydration products like monosulfoaluminate will be enlarged and occupy space at the interfacial transition zone between aggregate and paste [32-34] which finally decreases the flexural strength. It has been observed that the increase in 180 day flexural strength of $\mathrm{C} 1 \mathrm{~B}, \mathrm{C} 1 \mathrm{C}$, may be due to the additional and continuous formation of $\mathrm{CaCO}_{3}$ during wetting-drying periods. For this reason, some researchers found that the reaction between the amount of $\mathrm{CaCO}_{3}$ and the minerals in the cement, in particular $\mathrm{C}_{3} \mathrm{~A}, \mathrm{C}_{4} \mathrm{AF}$, produces a solid compound $\left(\mathrm{C}_{3} \mathrm{~A} \cdot \mathrm{CaCO}_{3} \cdot 11 \mathrm{H}_{2} \mathrm{O}\right)[6,19]$.

At the age of 360 days, $\mathrm{C} 1$ concrete is better than $\mathrm{C} 0$ in all environments, the results clearly show that the flexural strengths of different types are almost comparable in environment A. While in B, C1 and C1 IC concretes show an increase in flexural strength of $12.55 \%$ and $4.83 \%$ compared to C0. Similarly, C1C and C1C IC showed an increase of $15.51 \%$ and $10.98 \%$ compared to C0.

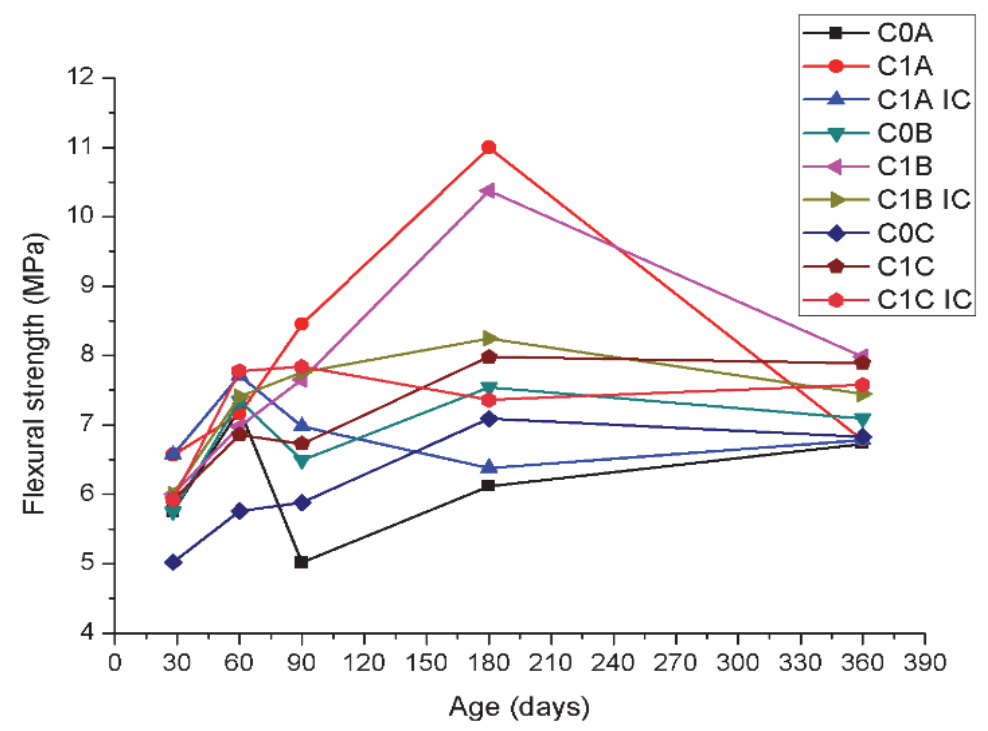

Figure 7: Evolution of flexural strengths of different concretes in the environment A, B and C. 


\section{Effect of substitution on mechanical strength: Tensile strength}

Fig. 8 describes the evolution of the splitting tensile strength over time. The results show that the concrete $\mathrm{C} 1$ reached a peak at the age of 28 days in all the environments, then the resistances of the same type of concrete were decreased over time and they were recovered again at the last deadline. However, the $\mathrm{C} 0$ concrete marked its high value in $\mathrm{A}$ at the same time as $\mathrm{C} 1$. On the other hand, in the B and C environment, it showed an improved resistance at 90 days.

This study allows us to compare the different splitting tensile strength by an obtained splitting at the beginning and at the end of the deadlines. It was found that the concrete $\mathrm{C} 1$ has evolved $8.95 \%, 40.62 \%$ and $9.38 \%$ at 28 days as well as $8.44 \%$, $15.59 \%$ and $1.80 \%$ at 360 days in $\mathrm{A}, \mathrm{B}$, and $\mathrm{C}$ respectively compared to the control concrete. Fig. 8 shows us in another way that the $\mathrm{C} 1$ specimens kept in environment B present results superior to the order of $4.95 \mathrm{MPa}$ and $4.3 \mathrm{MPa}$ at 28 and 360 days in succession compared to the other specimens in the other environments.

The results of the previous paragraph confirm once again that environment $\mathrm{B}$ favors the good hydration of cement compared to A and C. This situation is in agreement with those given in Tab. 3.

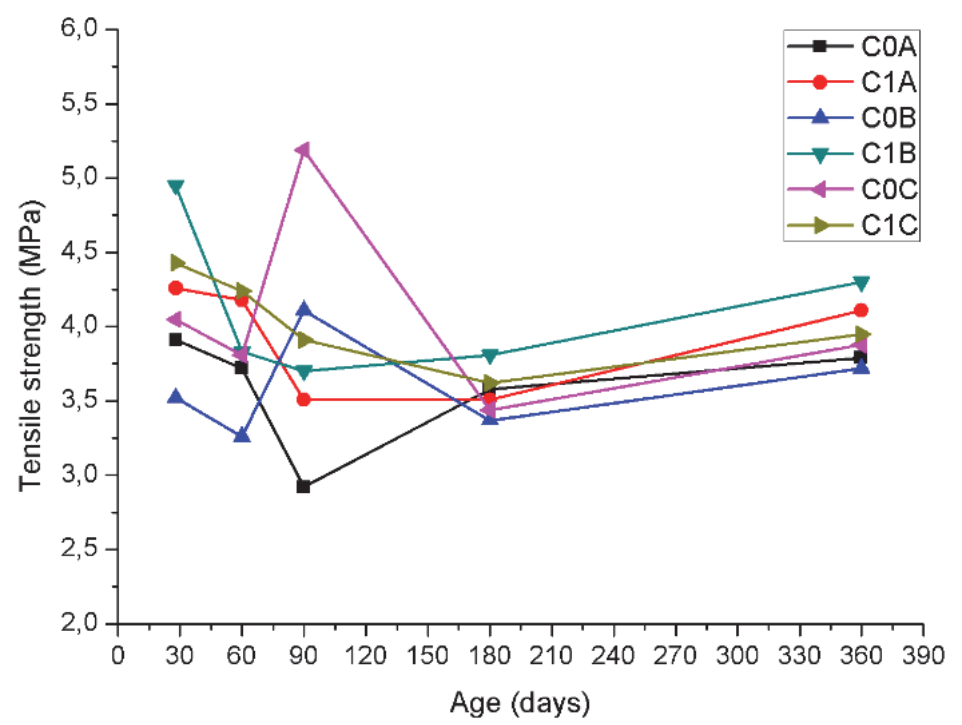

Figure 8: Evolution of tensile strengths of different concretes in the environment A,B and C.

\section{Effect of substitution on durability by FT-IR spectroscopy}

he FT-IR spectra (Fig. 9, 10,11) of all 360-day-old samples are almost similar. The main absorption bands in all samples in various environments are presented as the following:

The IR spectra of these 360-day old samples implanted in environment A are shown in Fig. 9. First, signals are due to ettringite, S-O at $1118 \mathrm{~cm}^{-1}$ of sample C0A, C1A and C1A IC and at $420 \mathrm{~cm}^{-1}$ for C0A, as well as O-H at $3410 \mathrm{~cm}^{-1}$ for all samples can be seen [35-37]. There were also O-H bands from sample C0A,C1A IC at $1029 \mathrm{~cm}^{-1}$ due to aluminate hydration products, $\mathrm{C} 3 \mathrm{AH} 6$ [38] and an $\mathrm{O}-\mathrm{H}$ absorption band at $428,459 \mathrm{~cm}^{-1}$ due to $\mathrm{AlO}_{6}$ at $\mathrm{C}^{\mathrm{A}} \mathrm{A}$ and $\mathrm{COA}$ respectively [36].

The infrared spectra of the composition of the study concretes (Fig. 9), indicate that the bands associated with different forms of gypsum were evident. Thus, the present spectra, in addition to the main band S-O of ettringite at $1118 \mathrm{~cm}^{-1}$, another absorption of S-O at 601, $671 \mathrm{~cm}^{-1}$ for C1A and C1A IC and $601,667 \mathrm{~cm}^{-1}$ from C0A explains the existence of gypsum. Another signal of the latter mineral of S-O band located at $1620 \mathrm{~cm}^{-1}$ between the two mixtures and regardless of the environment indicates Bassanite $\left(2 \mathrm{CaSO}_{4} \cdot \mathrm{H}_{2} \mathrm{O}\right)$ [35]. The results also show another $\mathrm{S}-\mathrm{O}$ band at $1103 \mathrm{~cm}^{-1}$ of hemihydrates at C1A [39].

An O-H band of aluminate hydration products, C3AH6 is found at $1029 \mathrm{~cm}^{-1}$ within sample C0A and C1A IC. In addition the $459 \mathrm{~cm}^{-1}$ band due to $\mathrm{AlO}_{6}$ observed within sample $\mathrm{COA}[36]$.

The absorption bands are observed for calcium carbonate phases are due to $\mathrm{CO}_{3}{ }^{-2}$ ion were numerous which are presented at 713, 875,1377, 1423,1797 and $2511 \mathrm{~cm}^{-1}$ of the C0A mixture and 709, 798, 875, 1392, 1435, 1465, 1477, 1797, 2511,470 , and $497 \mathrm{~cm}^{-1}$ of the C1A compound, finally the signals of C1A under continuous immersion (CI) are: 709, 798, $875,1419,1797$, and $2511 \mathrm{~cm}^{-1}[36]$. 

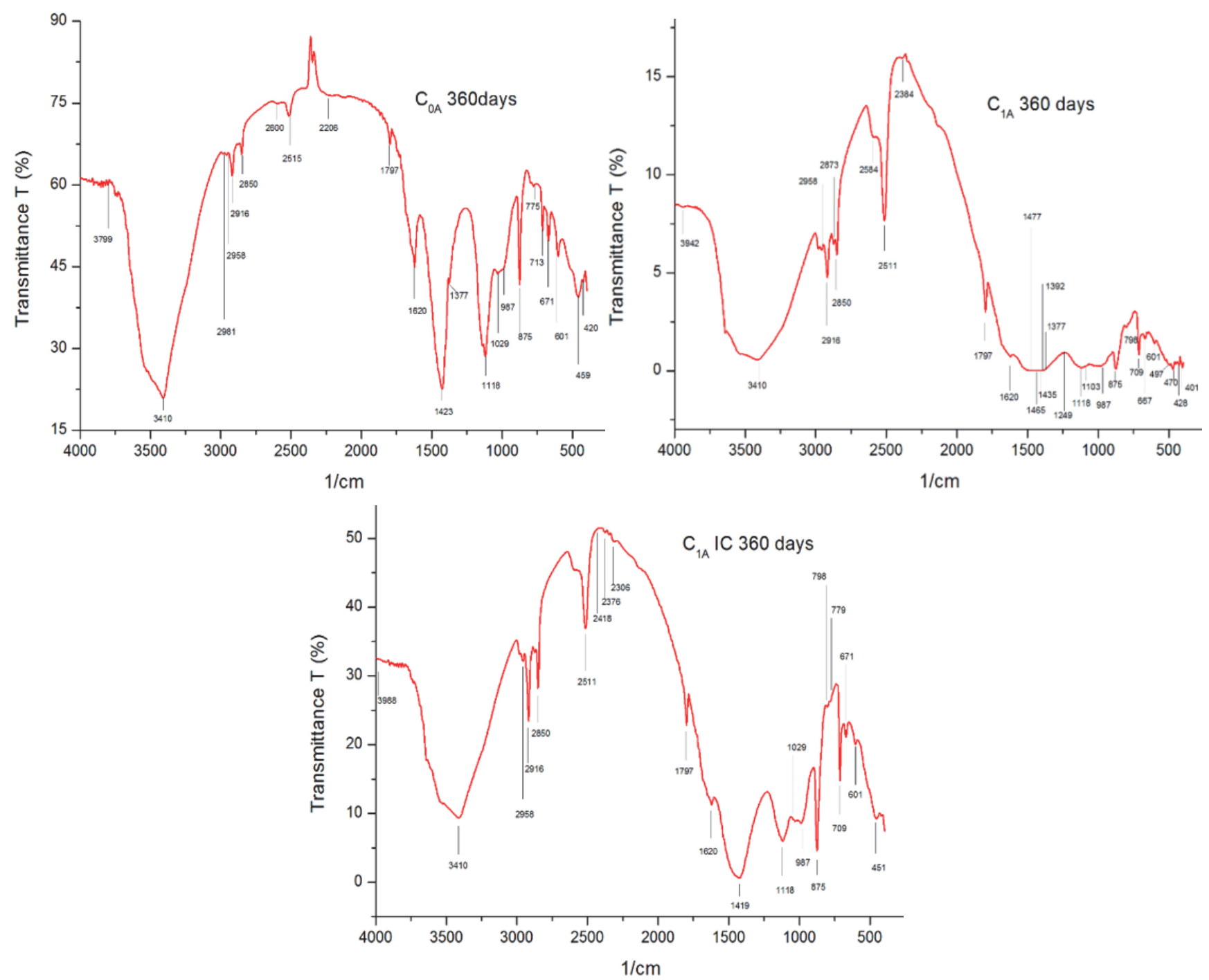

Figure 9: Infrared spectroscopies of C0A, C1A and C1A IC concrete at 360 days of age.

Concerning the environment B (Fig. 10), the FT-IR spectroscopy does not present any significant difference, the signals which are due to ettringite $\mathrm{S}-\mathrm{O}$ are always met at $1118 \mathrm{~cm}^{-1}$ in all the samples, and at $2191 \mathrm{~cm}^{-1}[40]$ of band $\mathrm{O}-\mathrm{H}$ in $\mathrm{C} 0 \mathrm{~B}$. One notices in this stage that the environment B is less infected by ettringite and gypsum. Indeed, the specters of gypsum in the various samples are located at the S-O bands: 601, $671 \mathrm{~cm}^{-1}$ as well as another at $1620 \mathrm{~cm}^{-1}$ representing the Bassanite. The O-H bands of aluminate hydration products, C3AH6 are found at: 1029, 1026 and $3525 \mathrm{~cm}^{-1} \mathrm{of} \mathrm{C0B}^{\mathrm{C}} \mathrm{C} 1 \mathrm{~B}$ IC and all samples respectively. Another additional O-H band is found at $3406 \mathrm{~cm}^{-1}$ indicates the existence of Bayerite $\mathrm{Al}(\mathrm{OH})_{3}$ in all samples, in addition to the $459 \mathrm{~cm}^{-1}$ band that is due to $\mathrm{AlO}_{6}[36]$.

Finally, the $\mathrm{CaCO}_{3}$ spectra are distributed at bands $713,779,875,1427,1797$ and $2515 \mathrm{~cm}^{-1}$ for the $\mathrm{C} 0 \mathrm{~B}$ mixture and 713 , $779,798,875,1419,1797$, and $2515 \mathrm{~cm}^{-1}$ from C1B and C1B IC.

From the environment $\mathrm{C}$ (Fig. 11), it is confirmed once again that the spectral behavior of the tested samples is much more similar than those of environments A and B. Initially, it can be said that the signals of the obtained ettringite are grouped in the following bands: a band $\mathrm{S}-\mathrm{O}$ at $1118 \mathrm{~cm}^{-1}$ represented in all the tested samples. Others are noticed within the O-H bands at 2198, 2191, 3417, and $3410 \mathrm{~cm}^{-1}$, the first and the last band show the fines of the COC and C1C IC concrete as well as the two intermediary ones, illustrate the $\mathrm{C} 1$ concrete. The S-O gypsum bands are localized as it has been seen before at the following regions: 601, 671, and $1620 \mathrm{~cm}^{-1}$ in the different samples. The compound C3AH6 is observed within the O-H bands: 1029, 3525, and $3545 \mathrm{~cm}^{-1}$, the first one indicates C0C concrete, C1C IC and the last two show C0C concrete. Bayerite $\mathrm{Al}(\mathrm{OH})_{3}$ is found at the $\mathrm{O}-\mathrm{H}$ band at $3406,3545 \mathrm{~cm}^{-1}$ regions of the $\mathrm{C} 0 \mathrm{C}$ sample. The $\mathrm{AlO}_{6}$ band is restricted to $459,416 \mathrm{~cm}^{-1}$ within the $\mathrm{C} 0 \mathrm{C}$ and $\mathrm{C} 1 \mathrm{C}$ samples. 

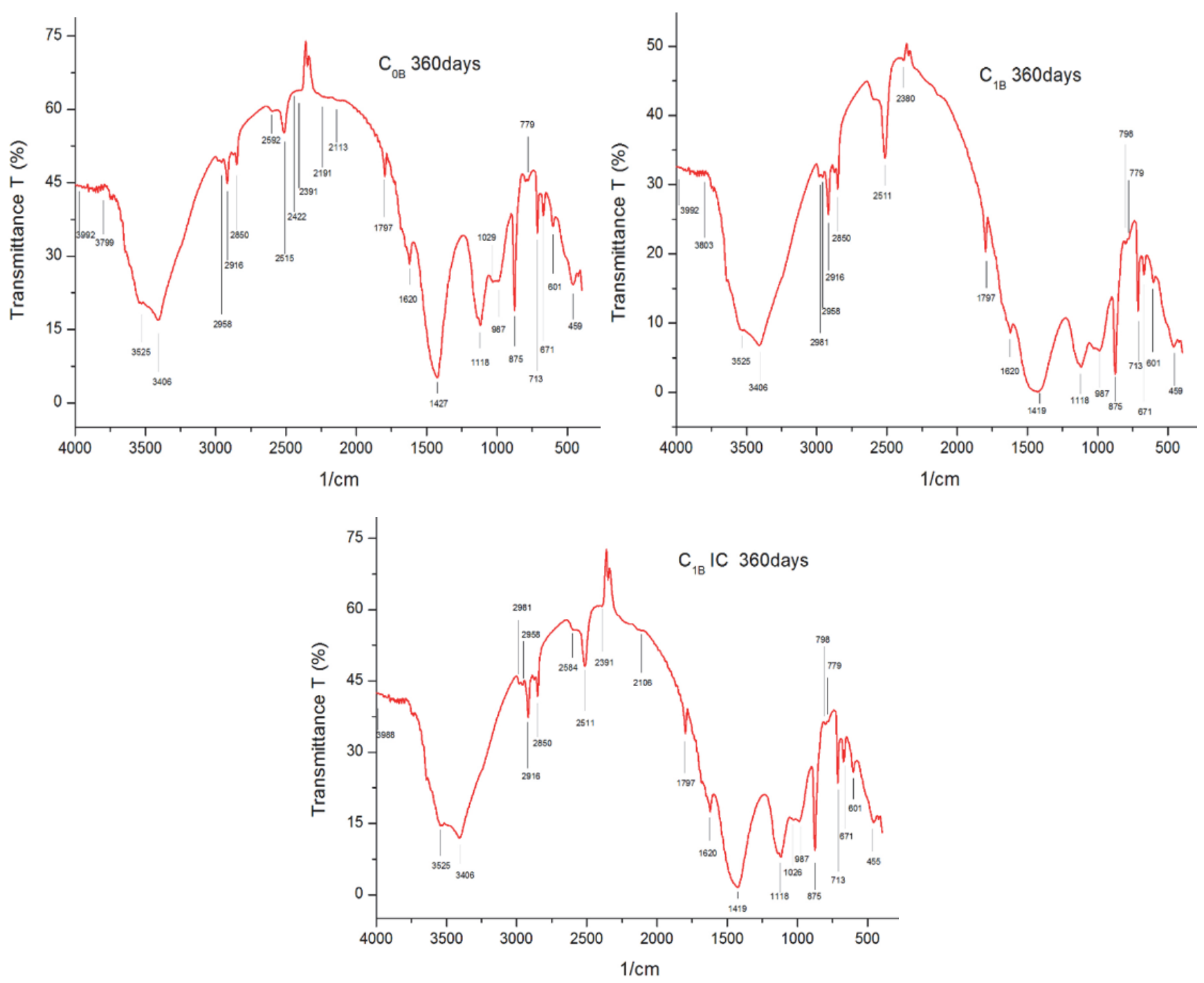

Figure 10: Infrared spectroscopies of C0B, C1B and C1B IC concrete at 360 days of age.

The $\mathrm{CaCO}_{3}$ spectra are equally distributed at the $\mathrm{CO}_{3}^{-2}$ bands: 713, 779, 875, 1427, 1797, 1863, and $2511 \mathrm{~cm}^{-1}$ for the $\mathrm{C} 0 \mathrm{C}$

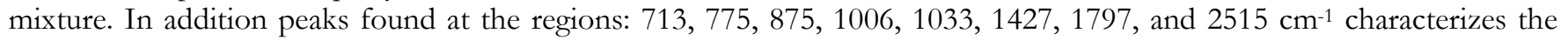
C1C concrete and finally the C1C IC mixture also shows that the peaks are localized at the following locations: 713 , 779, $875,1396,1446,1469,1797$, and $2511 \mathrm{~cm}^{-1}$.

Generally and in all environments, it was noticed that more intense peaks (signals) of ettringite and gypsum in the C0 samples. The calcite are in great quantity resulting from the conversion of $\mathrm{Ca}(\mathrm{OH})_{2}$ to $\mathrm{CaCO}_{3}$. This finding certainly indicates the advantage of using concrete that it based on an equal percentage of limestone sand and silica sand than ordinary concrete that are based on silica sand in a chemically aggressive environment.

\section{CONCLUSION}

he use of half of the sand in a concrete formulation as sand from limestone crushing gives favorable results compared to conventional concrete. After this study, the following remarks can be drawn:

- The concrete based on 50\% river sand and 50\% crushed limestone sand gains the best specific weight according to a well chosen plasticity range. 

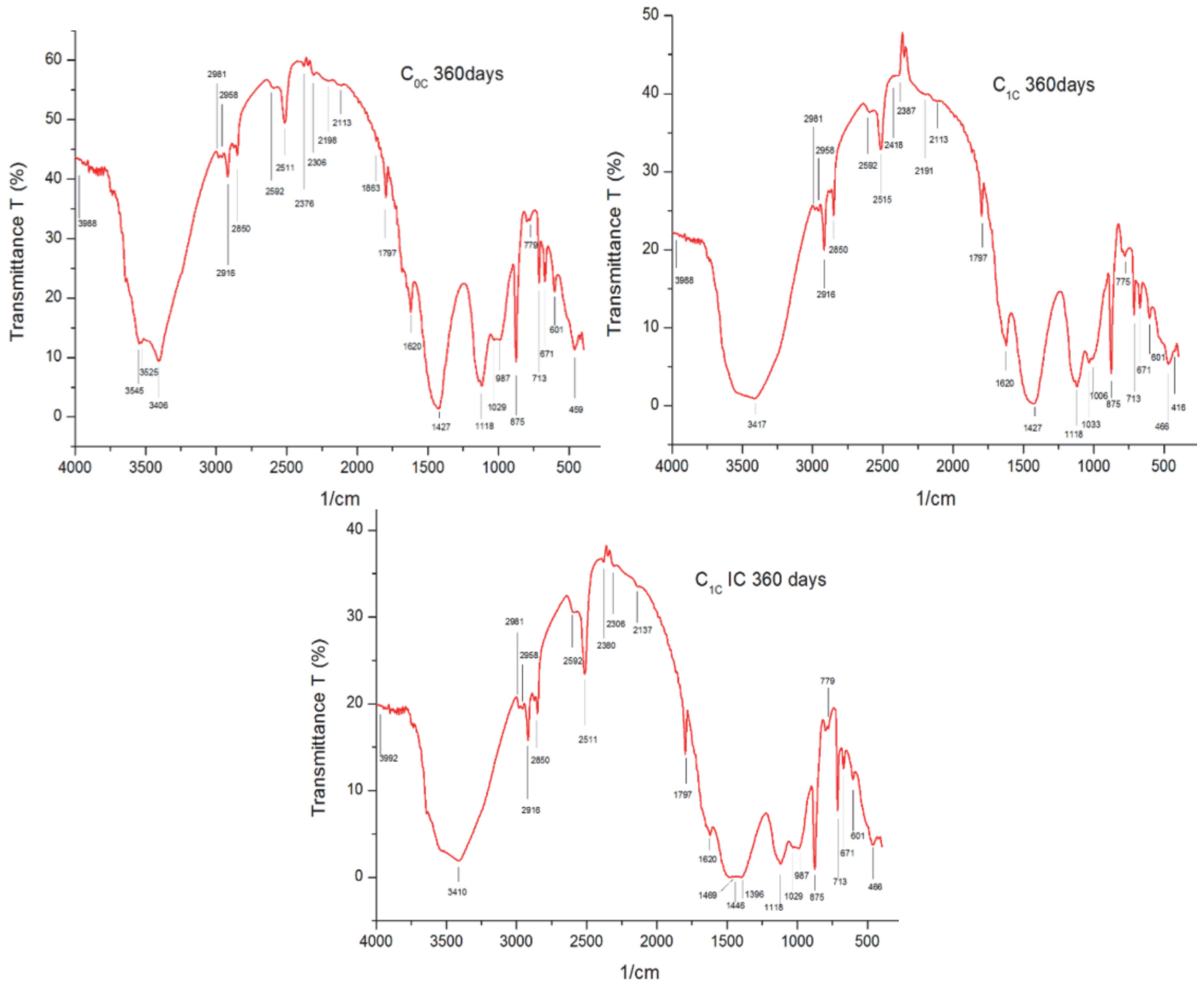

Figure 11: Infrared spectroscopies of C0C, C1C and C1C IC concrete at 360 days of age.

- A statistical correlation was obtained when measuring the workability and the corresponding specific weight with coefficient $\mathrm{R}^{2}=0.95$. This polynomial form approach can give a preliminary indication of the compactness during the measurement of the workability.

- In the rising water table and in any studied environment in this investigation, the underground structures that are built with silica-limestone sand show higher mechanical strength compared to those built with natural river sand.

- The followed policy for the degradation of the samples is based on the use of alternative cycles of wetting-drying is very interesting and proves that the continuous immersion favors a good chemical hydration of C-S-H and $\mathrm{CH}$ and generates good mechanical strengths of all the elaborated samples.

- Intense harmful hydration products were created from the conventional concrete compared to the studied concrete such as ettringite and gypsum.

- Increased number of ettringite and gypsum peaks and other aluminate products in control samples compared to silica-limestone sand concrete $(50 / 50) \%$.

- The positive effect of limestone in sand based concrete of equal percentage of silica and limestone was certainly noticed by the formation of a whitish layer on the outer surface of the specimens, which also creates a barrier against the infiltration of aggressive agents inside the concrete.

- The limestone grains are cheaper and available compared to the silica ones, which are in strong daily decline. This solution helps to decrease the overall cost of the works and preserve the environment. 


\section{NOMENCLATURE}

$\begin{array}{ll}\text { RS } & \text { River sand } \\ \text { CS } & \text { Crushed sand } \\ \text { XRD } & \text { X-Ray diffraction } \\ \text { C 30/37 } & \text { Compressive strength class 30/37 } \\ \text { W/C } & \text { Water/Cement ratio } \\ \text { CG } & \text { Crushed gravel } \\ \text { G1 } & \text { Gravel }(3 / 8) \\ \text { G2 } & \text { Gravel }(8 / 16) \\ \text { FT-IR } & \text { Fourier-transform infrared spectroscopy } \\ \text { XA2 } & \text { Moderate aggressive environment } \\ \text { SP } & \text { Superplasticizer }\end{array}$

\section{REFERENCES}

[1] Alger, E.N.G.(1999). Document: Sable la nouvelle donne, Algérie, pp. 01-05.

[2] Ahmad, S. and Mahmood, S. (2008). Effects of crushed and natural sand on the properties of fresh andhardened concrete. In: 33rd conference on our world in concrete and structures, Singapore, 100033006.

[3] Elavenil, S., Vijaya, B. and Hariharan, K. (2005). Manufactured sand, a solution and an alternative to river sand and in concrete manufacturing. J Eng Comput Appl Sci (JEC\&AS), 2(2), pp. 20-24.

[4] Mounir, L. and Idrees, Z. (2019). Effect of total substitution of crushed limestone sand on concrete durability, European Journal of Environmental and Civil Engineering. DOI: 10.1080/19648189.2019.1649199.

[5] Ahmed Ahmed, E. and Ahemed Kourd, A. E. (1989). Properties of concrete incorporating natural and crushed stone very fine sand, ACI Material Journal, 86(4), pp. 417-424.

[6] Neville, A. M. (1995). Properties of concrete. Fourth edition, England, Longman, pp.844.

[7] Chi, C., Wu, Y. and Riefler, C. (2004). The use of crushed dust production of self consolidating concrete (SCC), Recycling Concrete and other materials for sustainable development.ACI Symposium, 219, pp. 115-130.

[8] Kenai, S., Benna, Y. and Menadi, B. (1999). The effect of fines in crushed calcareous sand on properties of mortar and concrete. Proceedings of the International Conference on Infrastructure regeneration and rehabilitation, Sheffield, pp. 253-261.

[9] Djedid, T., Guettala, A. and Mani, M. (2019). Study of the workability and mechanical strength of concrete in the face of upwelling (Case of the El Oued region of Algeria. J Fundam Appl Sci. 11(1), pp. 368-384. DOI: $10.4314 /$ jfas.v11i1.24. ISSN 1112-9867.

[10] CCAA, T 60. (2008). Guide to the specification and use of manufactured sand in concrete, Australia, Cement concrete aggregate, pp. 1-15.

[11] Shanmugapriya, T. and Uma, R. N. (2012). Optimization of partial replacement of M-S and by natural sand in high performance concrete with silica fume. Int J Eng Sci Emerg Technol, 2(2), pp.73-80.

[12] Puneeth, G. T., Mamatha, A. (2016). An experimental investigation on the strength of concrete by partial replacement of cement with micro silica and naturel sand with manufactured sand. International Journal of Civil and Structural Engineering Research, 3 (2), pp. 52-57.

[13] Nisnevich, M., Sirotin, G. and Eshel, Y.(2003). Light weight concrete containing thermal power station and stone quarry waste, Magazine of Concrete Research, 55, No. 4, pp. 313-320. Doi:10.1680/macr.2003.55.4.313.

[14] Prakash, Rao. D. S. and Kumar, V. G. (2004). Investigations on concrete with stone crusher dust as fine aggregate. Indian concrete journal, 78(7), pp. 45-50.

[15] Vasumathi, A.M. (2003). A study on the strength of the concrete by partial replacement of cement with fly ash and sand with quarry dust, Proceedings of National Seminar on Futuristics in Concrete and Construction Engineering, S.R.M Engineering College, Chennai, pp. 8-14.

[16] Dreux, G. and Jean, FESTA. (1998). Nouveau guide du béton et de ses constituants. Paris, Eyrolles. p. 416.

[17] EN 12350-2. (1999). Essais pour béton frais - Partie 2: Essais d'affaissement. Institut de normalisation, Serbie.

[18] EN 12350-6. (1999). Essai pour beÂton frais - Partie 6: Masse volumique. Institut de normalisation, Serbie.

[19] Neville, A. and Brooks, J.J. (2010). Concrete technology.Second Edition. ISBN.978-0-273-73219 8(pbk). 
[20] NF EN 12390-3. (2003). Essai pour béton durci - Partie 3: résistance à la compression des éprouvettes, France, AFNOR.

[21] NF EN 12390-5. (2001). Essai pour béton durci - Partie 5: résistance à la flexion sur éprouvettes, France, AFNOR.

[22] NF EN 12390-6. (2000). Essai pour béton durci - Partie 6: Résistance en traction par fendage d'éprouvettes, France, AFNOR.

[23] NF EN 206-1. (2004). Béton - Partie 1: Spécification, performances, production et conformité, France, AFNOR.

[24] Lei, Jiang, A. and Ditao, N. B. (2016). Study of deterioration of concrete exposed to different types of sulfate solutions under drying-wetting cycles. Construction and Building Materials, 117, pp. 88 - 98,

DOI: 10.1016/j.conbuildmat.2016.04.094 0950-0618/_ 2016 Elsevier Ltd.

[25] Ahmed, M. D., Abd Elmoaty, M., and Ayman, A. Aly.(2016). Long term study of mechanical properties, durability and environmental impact of limestone cement concrete. Alexandria Eng. J.55 (2), pp. 1465-1482, DOI: 10.1016/j.aej.2016.01.031.

[26] Swapnil, S. F. (2014). Concrete with Smart Material (Manufactured Crushed Sand)- A Review. International Conference on Advances in Engineering \& Technology. Journal of Mechanical and Civil Engineering, 6(11), pp. 2729.

[27] Kamali, S., Gerard, B., and Moranville, M. (2003). Modelling the leaching kinetics of cement based materials-influence of materials and environment. Cem Concr Compos; 25, pp. 451-458. DOI: 10.1016\%2FS0958-9465(02)00085-9.

[28] Agostini, F., Lafhaj, Z., Skoczylas, F. and Loodsveldt, H. (2007). Experimental study of accelerated leaching on Hollow cylinders of mortar. Cem. Concr. Res., 37, pp. 71-78. DOI: 10.1016/j.cemconres.2006.09.018.

[29] Bederina, M., Makhloufi, Z., Bounoua, A., Bouziani, T., Queneudec, M. (2013). Effect of partial and total replacement of siliceous river sand with limestone crushed sand on the durability of mortars exposed to chemical solutions, Construction and Building Materials, 47, pp.146-158. DOI: 10.1016/j.conbuildmat.2013.05.037.

[30] Priyanka, A.J. and Dilip, K. K. (2013). Effect of replacement of natural sand by manufactured sand on the properties of cement mortar. International Journal of Civil and Structural Engineering, 3, pp. 621-628.

DOI: 10.6088/ijcser.2 201203013057.

[31] Adams, J.M., Rajesh, A.M., Brightson, P. and Anand, M.P. (2013). Experimental Investigation on The Effect Of MSand In High Performance Concrete, American Journal of Engineering Research (AJER); V 02, pp. 46-51.

[32] Kumar Mehta, P. and Monteiro, P. J. M. (2006). Concrete Microstructure, Properties, and Materials, Third Edition, New York, McGraw-Hill. DOI: 10.1036/0071462899.

[33] Tokyay, M. (2016). Cement and concrete mineral admixtures, Middle East Technical University, Ankara, Turkey, CRC Press. Taylor \& Francis Group, p.325.

[34] Mani, M., Bouali, M. F., Kriker, A. and Hima, A.(2021).Experimental characterization of a new sustainable sand concrete in an aggressive environment,Frattura ed Integrità Strutturale, 55 (1), pp.50-64, DOI: 10.3221 /IGF ESIS.55.04.

[35] Fernandez-Carrasco, L., Torrens-Martin, D., Morales, L.M. and Martinez- Ramirez, S. (2012). Infrared spectroscopy in the analysis of building and construction materials. In: Infrared spectroscopy—materials science, Engineering and technology. London, INTECH open edition, pp. 369-382.

[36] Trezza, M.A. and Lavat, A. (2001). Analysis of the system 3CaO.Al2O3-CaSO4.2H2O-CaCO3-H2O by FT-IR spectroscopy. Cement and concrete Research 31, pp. 869-872, DOI: 10.1016/S0008-8846(01)00502-6.

[37] Djedid, T. (2020). Effet de la substitution du sable de rivière par du sable de carrière sur la durabilité des bétons à base de différents ciments algériens dans des environnements chimiques. Thèse de doctorat en Génie Civil. Univ Biskra. 213p.

[38] Fernandez-Carrasco, L. and Vazquez, T. (1996). Aplicacion de la espectroscopia infrarroja al estudio del cemento aluminoso. Mater. Constr., 46, pp. 53-65. DOI: 10.3989/mc.1996.v46.i241.540.

[39] Mandal, P. K. and Mandal, T. K. (2002). Anion water in gypsum (CaSO4-2H2O) and hemihydrate $\left(\mathrm{CaSO}_{4}-1 / 2 \mathrm{H}_{2} \mathrm{O}\right)$. Cem. Concr. Res.,3 2, pp.313-316.

[40] Ramachandran, V. S. and Beaudoin, J. (2000). Handbook of analytical techniques in concrete and technology Principles, Techniques, and Applications. England, William Andrew publishing. 